\title{
EFFECT OF PRIVACY ON AND ELEMENTS OF IDENTITY IN MUSLIM-TURKISH HOUSES IN ANATOLIA
}

\author{
ETİAKYÜZ LEVİ \\ Department of Architecture, Dokuz Eylül University, İzmir, Turkey \\ E-mail: eti.akyuz@gmail.com
}

\begin{abstract}
Culture" has a featured place among a large number of factors which are effective on the formation of house architecture. From time to time, it is observed that very different houses are formed in the same physical environment. Sometimes analogous houses can be seen under highly different environmental conditions. It is possible to mention the effects of different cultures and lifestyles on this. The study aims to reveal how the effect of privacy is reflected in spatial formation and architectural elements in Muslim-Turkish houses. The relationship of the Turkish House with the concepts of Ottoman, Anatolia, Muslim and tradition as well as coincidence and variations are addressed. The analytical and comparative method is employed in the study. The common elements in the architectural formation which are caused by the vital and cultural interactions in the Turkish houses in Anatolia and the Balkans are reflected in the form of analogies in the building façade character and in architectural elements. It is possible to gather the analogies in the Turkish houses not only in the context of Anatolia and the Balkans but also at different corners of Anatolia under the common ground of "culture". The effects of culture are reflected in the house architecture in a wide range from the use of lattice in various spaces and elements to kapl şakşaks besides the openings which vary on the building façades depending on location and story.In this study, the concept of Turkish House and the thorough investigations into this issue are considered and the effect of the factor of "privacy" on the formation of Muslim-Turkish houses in Anatolia is examined from different perspectives. The subject is presented via the examples of Turkish houses selected from various localities of Anatolia. How the inward character of the Turkish house and its understanding of privacy are reflected in the details of an architectural building besides its façade and spatial construct is conveyed via examples. The thorough investigation concerned is of importance to see how culture and lifestyle are reflected on architecture - in other words, to read culture from the formation of a house.
\end{abstract}

Keywords: Turkish House, privacy, identity, Muslim, inwardness.

1. Introduction. In this study on reading the effect of culture on house architecture, it was intended to thoroughly investigate the formations which were the reflections of privacy in Muslim-Turkish Houses via examples. The study aims to make evaluations of the Turkish houses with a significant place in house architecture and to thoroughly investigate the reflection of the factor of privacy in space. The subject is addressed with the analytical and comparative method in the study carried out to find an answer to such questions as how the Turkish House is related to the concepts of Ottoman-Turkish House, Anatolian-Turkish House, Muslim-Turkish House, and Traditional Turkish House; what can be said in the context of the 
sameness of, and differences in, the concepts concerned; and how the analogies of the Turkish houses in Anatolia and the Balkans can be elucidated. The study covers the examples of Turkish Houses in Anatolia and also includes a comparison with the examples in the Balkans. The common elements resulting from cultural and vital interactions are exemplified. The research includes the sections of the concept of Turkish house, a thorough investigation into the formations for privacy in Muslim-Turkish Houses, elements of identity, and conclusion.

2. Concept of Turkish House. In the historical process, the Turkish House has been the subject of various studies and different approaches to its origin and typological thorough investigation have been set forth. Making a connection with the nomadic culture and "oba settlement" attracts attention in the research on the origin of the Turkish house $[1,2]$. The fact that the Turks who came from Central Asia have the nomadic culture is effective on this. Considering that tents are pitched around a square in the nomadic order and that each tent answers all life functions, as does a house, those who relate the Turkish House to the nomadic culture $[1,2]$. indicate the sofa (hall) and the room as the equivalents of these spaces. Truly, the square encircled by all tents is equivalent to the sofa (hall) space that all rooms in a Turkish House lead to and that is the space for dispersal and assembly. With their flexible spatial order and fixed architectural elements (e.g. yüklük (a large built-in cupboard) and sedir), the rooms also assume different functions in different time spans. That's why every room is like a house; furthermore, a room is also called a "hane", meaning a house, at some localities.

In typological studies on the Turkish House, it is seen that various researchers made a classification on the basis of a different element.

S.H. Eldem, who made comprehensive studies on the Turkish House, defines a Turkish House as follows:

"The Turkish House which has settled, developed and been utilized for 500 years in Anatolia and Rumelia, has been accepted by the Turks by fifteenth and sixteenth centuries and achieved its most rapid expansion tendency during seventeenth and eighteenth centuries" [3].

Eldem makes his grouping on the basis of the uppermost floor, the actual floor which determines the plan of a house, i.e. the element of "sofa (hall)". Accordingly, he classifies Turkish houses as those without sofa (hall), with an outer sofa (hall), with an inner sofa (hall), and with a central sofa (hall) [3]. The classification concerned was made depending on the location and presence of the element of sofa (hall). The types develop depending on time and the fact that the climate becomes harsh and from primitiveness to development.

Kuban, however, makes an evaluation by considering the room and some of the dispersal space a module [4]. With his approach concerned, he emphasizes the significance of several elements, but not of a single element. Esin regards the element of köşk, Arel the başoda and Aksoy the orta mekân (central space) as the actual element in a Turkish house. Arel states that the fundamental foundation principle of a Turkish house is contrast - in other words, "the coexistence of contrasting elements within the spatial system" [5]. Truly, in the houses, it is possible to read the striking indicators of contrast such as the downstairs that has taken shape in the irregular parcel order and the upstairs that has acquired an order which will include perpendicular spaces with protrusions(şahnişin); the garden façade which is as transparent as possible despite the street façade where inwardness prevails; and the upstairs that has gained motion with protrusions and eaves despite the downstairs that reflects a plain and steady wall surface on the street façade. 

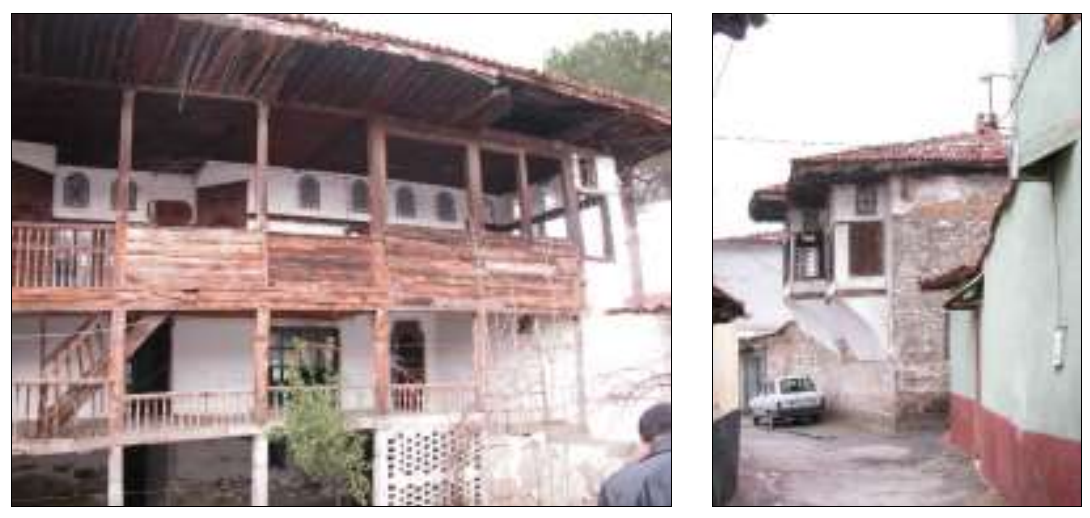

Figure 1 - 2. Kula Beyler House garden facade and street facade

Considering the principles in the gathering order of the core spatial units in a traditional Anatolian house, Erdim made an analysis according to the spatial unit typology by taking synchronical and diachronical relationships into consideration. He expressed that a Turkish house could be reduced to a repeatable functional unit. He mentioned the home spaces as örtme (hayat), iwan, and other interior spaces (rooms and stables) and classified them as A.1 (a unit house with an iwan, with the iwan being lateral or central) and B.1 (a unit house with an örtme) [6].

Although the sofa (hall) - hayat in the houses with an outer sofa (hall) - is regarded as the focal space of the house, the focal space is also observed to differ in the Turkish houses at different localities in the Anatolian geography. For instance, even though the "hayat" space is generally used in the sense of a sofa (hall), it is used in the sense of a courtyard in some settlements in the central and eastern parts of Anatolia. The hayat, i.e. the place where life takes place in the house, may differ. For instance, a courtyard is called a hayat in the Houses of Avanos. The cooking space described as tokana or togana in the houses of Kayseri and the multifunctional space called tandırevi in the houses of Erzurum are the focal spaces of the house [7, 8]. In the Houses of Divriği, the toyhane is the focal space [9].

The remarkable thing notwithstanding the different perspectives concerned is some characteristics in the Turkish House. Inwardness may be stressed among them. It may be stated that this characteristic plays a significant role in the formation of a house.

What attracts attention in different typological evaluations is "the difficulty in the generalization" of the Turkish Houses which have spread over highly extensive geography. From time to time, the typological studies presented are criticized by other researchers for not conforming to the examples in some geography. For instance, while the analysis by Eldem conforms to the examples in İstanbul and Western Anatolia, the importance of the element of iwan in the houses in South-eastern Anatolia has required more different evaluations.

One of the most striking characteristics of a Turkish House is "spatial fluidity". The presence of integrated and separate subspaces which flow into each other adds some distinct richness to the house. Besides, the feature of a half-open space between open and closed spaces is also magnificent spatial richness. The presence of subspaces that the spaces contain or integrate with is a remarkable characteristic of a Turkish house. 


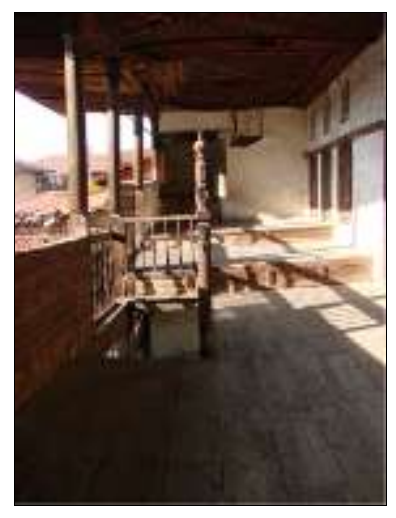

Figure 3. Kula Beyler House's Sofa

The raised sekis at the two corners of the open outer sofa (hall) are spaces which both separate from and integrate with the sofa (hall). Likewise, iwans in the houses with a central sofa (hall) are subspaces which both integrate with and separate from the sofa (hall). In the houses with an open outer sofa (hall), the sofa (hall), the seki and the garden can be given as examples in the context of the spaces which flow into each other. The subspaces of a room can be described as the entrance, the sekialtı, and the sekiüstü.

The "inwardness" of a Turkish House is a reflection of the understanding of privacy and has resulted in the formation of an almost distinct world which is disconnected from the street and the outer environment and which has integrated with the garden and nature. The garden and the element of water in the garden can also be mentioned among the striking characteristics of a Turkish house.

2.1. Conceptual Discussions on the Turkish House. The terminology used in the things conveyed regarding the Turkish House is generally in the form of "Turkish house", while it also appears in the form of "Muslim-Turkish House", "Ottoman-Turkish House", "Traditional Turkish House", and "Anatolian-Turkish House" in different contexts. The emphasis on religion attracts attention in the expression "Muslim-Turkish House", whereas the power of the Ottoman Empire that spread over the continents and the Turkish houses presented in these territories in connection with it are considered in the expression "Ottoman-Turkish House". The Turkish Houses formed with the experience handed down from one generation to the other are considered with the expression "Traditional Turkish house". Anatolian-Turkish Houses include the Turkish Houses in the Anatolian geography.

Some researchers state that it is wrong to call a Turkish House an "Ottoman House", for Ottoman Houses may encompass all houses of the subgroups living in the Ottoman Empire [10].

There are also researchers who evaluated the use of the expressions "Turkish House" and "Ottoman-Turkish House" in the chronological context. Tuztaşı and Aşkun stated that Eldem preferred using the term "Turkish House" between the 1950s and the 1980s but included the expression "Ottoman-Turkish House" after 1980 [11].

Different ideas may be brought forward when it is intended to answer the question "How identical and separate are these different expressions that are contained under the umbrella of "the Turkish House"?". It might be stated that the word "Turkish" reflects nationality and that the people who are citizens of the Republic of Turkey are described as "Turkish". When considered in this context, the approach that "the Turkish House" is the house of Turks will not be incorrect. Here the issue of whether the person who has that house constructed or the person who lives in that house is Turkish creates a different discussion. When a Muslim-Turkish House is mentioned, one considers the houses of Muslim Turks. People who are Turkish, or in other words who have lived in the Turkish territories for generations, but not Muslim and belong to different religions (Christian and Jewish) are also available in the population, although at a very small rate. When an Ottoman-Turkish House is mentioned, one considers the Turkish Houses within the Ottoman geography, where the Empire carried on its sovereignty in the past and which covers a very large area in the world. Hence, its scope considerably exceeds the Anatolian boundaries. Many of these examples have now remained within the boundaries of different countries. It is possible to read the Ottoman traces and see 
examples of the Turkish House in Bulgaria, Greece, Albania, etc. In conclusion, these concepts are umbrellas with different diameters which have overlapped each other by sliding and partially coincide with each other.

In her study on the Ottoman houses in the Balkans, Akın also indicated the presence of houses which were highly analogous to the examples in Anatolia and revealed the common cultural unity. Akın states that the reflection of coexistence and the exchange of culture in architecture created common elements between Anatolian and Balkan houses which vary by the distance from the centers of government [12]. She emphasizes that the common features in the houses in Anatolia and the Balkans, which she describes as "the joint product of the Ottoman cultural environment", are in the context of room furnishings and decorations, along with being common elements in design [13].

As the characteristic of an Ottoman-Turkish house, the downstairs is as solid and inward as possible and the relationship with the street is formed through the upstairs protrusions and windows in the examples in the Balkans as well. The protrusions upstairs add activity to the building and the street. The courtyard walls are high and solid, while the courtyard gates are solid and wooden. The characteristic of the garden façade as being transparent and integrated with nature is also seen in the examples there. Başodas draw attention as the most remarkable space of the house.

The most important analogies of the Ottoman-Turkish houses in Anatolia and the Balkans are such spaces as the courtyard and the hayat [13].

There are also people who ascribe the analogies of the houses to the coincidence of the group of itinerant masters who constructed them [14].

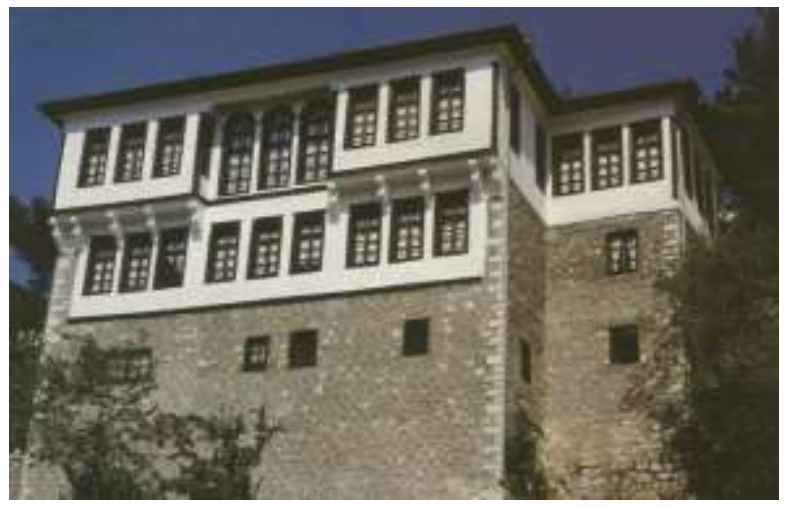

Figure 4. House in Kesriye (Greece) similar to Anatolian Turkish Houses [13]. Reference: Akın, 2001, p. 100.

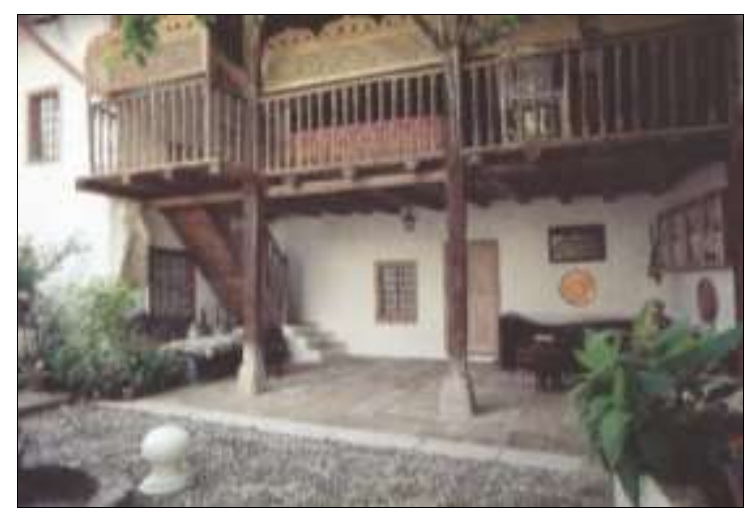

Figure 5. House in Bosna similar to Anatolian Turkish Houses [15].

Reference: Günay, 1999², p.60.

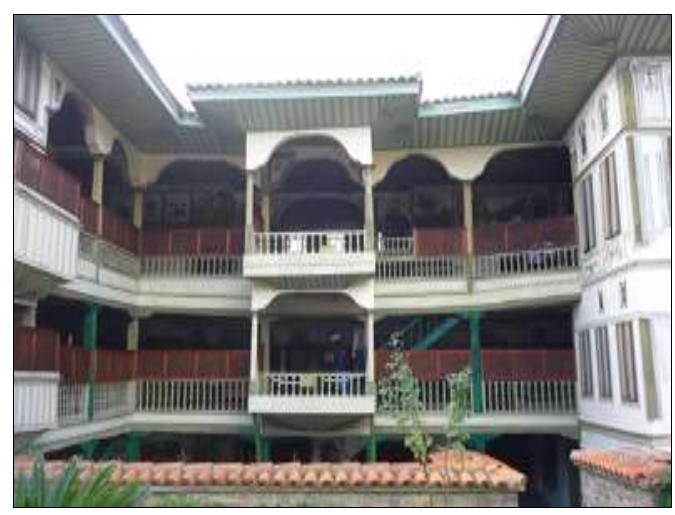

Figure 6. Birgi Çakırağa House 
3. A Thorough Investigation into the Formations for Privacy in Muslim-Turkish Houses. In Muslim-Turkish Houses, privacy has been reflected in architecture in different contexts. In the study, the subject is addressed in four groups, namely in terms of façade openings, in terms of façade elements and other architectural elements, in terms of spatial elements, and in terms of location.

3.1. In terms of façade openings. Muslim-Turkish Houses are generally two-story buildings where the downstairs is divided into service spaces and the upstairs reflects the quality of a living floor. In the parcel pattern, the wet spaces like the toilet are located to be separated from the main building mass. In the houses located at irregular parcels, the downstairs order is in agreement with the parcel, while protrusions have been built to create regular spaces upstairs. In the façades frequently formed by consecutive triangle projections, every room behind the façade is reflected outside so that the plan can also be read from the façade. When the façades of a building are viewed, it is seen that the street façade is almost entirely solid downstairs and that its connection with the street and the outer environment is provided through the windows and the protrusions upstairs. The street façade is as closed as possible as the reflection of privacy, while the garden façade is entirely transparent (open) with the hayat and hayataltı spaces and the house has integrated with the garden and nature particularly in the examples with an open outer sofa (hall).

3.2. In terms of façade elements and other architectural elements. In Muslim-Turkish Houses, privacy is also reflected in façade and interior space elements. The garden walls are stone, solid, and high unlike the semipermeable walls with iron railings seen in the houses under the Western influence. In this way, the person who passes from the street is prevented from seeing the person in the garden and the life there. The gates for entry into the building generally from the garden, i.e. the garden gates, are wooden, two-leaf, and solid. The element of lattice, which allows one to see the outside without being seen from the outside, is frequently used at the windows on the façade. The element of lattice concerned is seen above the railings in the sofa (hall) and seki spaces and at the periphery of the element of abdestlik in the sofa (hall) besides windows and oriel windows. In some examples, the lateral façade of the sofa (hall) space is closed with a stone wall or a wooden lattice in order to prevent being seen from the road or the neighbor. One of the architectural elements on the façade is "the kim geldi penceresi", which is located upstairs and allows one to see who has come to the house without going downstairs or being seen from the outside when someone knocks on the door.
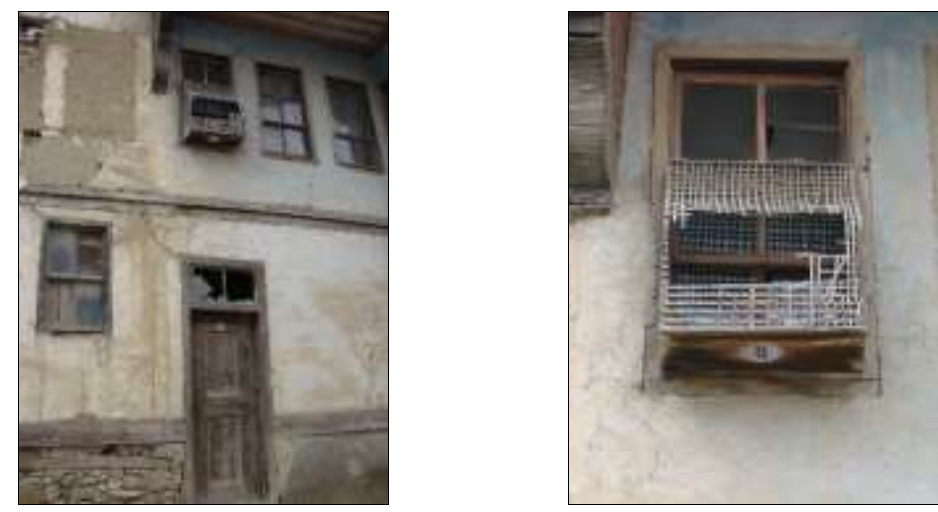

Figure 7-8. Tarakl - The "kim geldi penceresi" element 


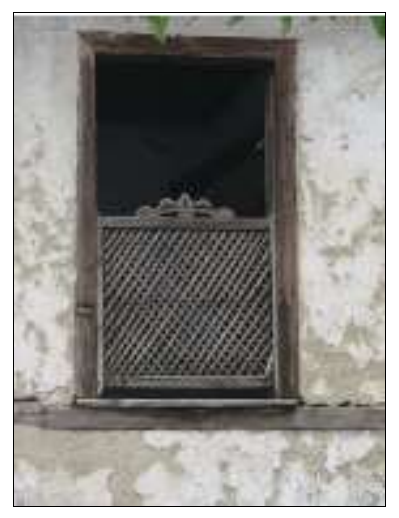

Figure 9. A lattice element in Taraklı

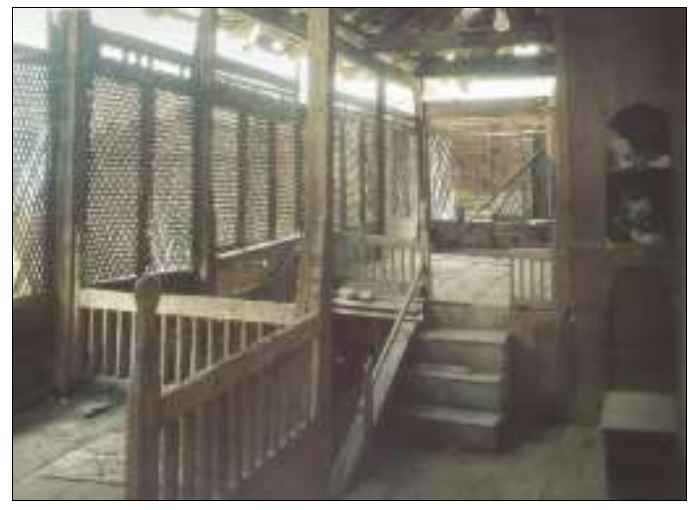

Figure 10. A lattice element is seen above the railings in the sofa [15]. Reference: Günay, 1999², p.178.

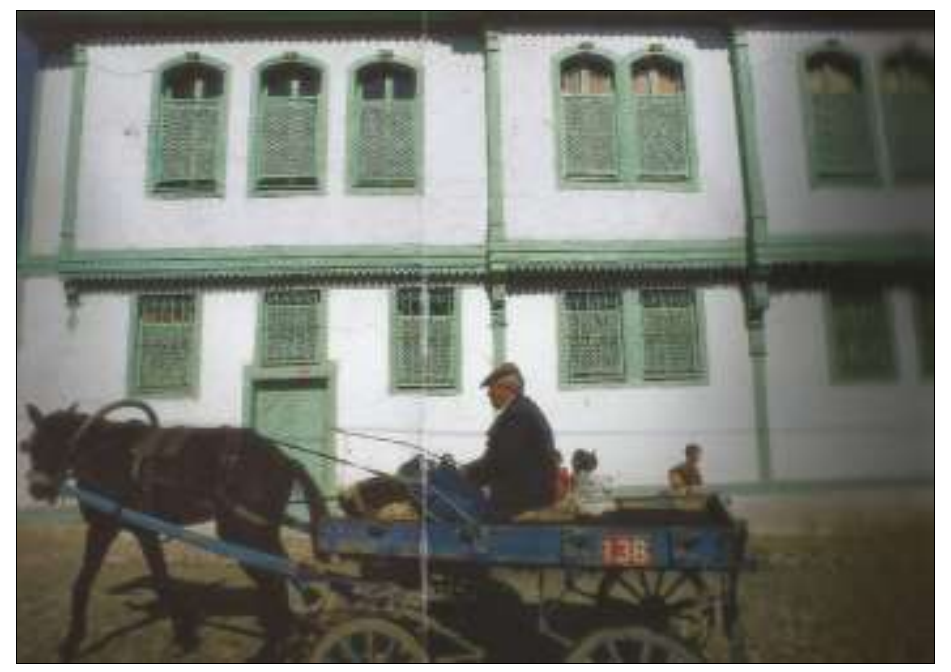

Figure 11. Lattice elements are seen on the street façade - Afyon (Bolvadin) [18]. Reference: Eczacıbaşı, 2003, p.152. 
Another exterior façade element created under the influence of privacy is the kapı şakşaks. There are two şakşaks at the door of houses at some localities. From the sound produced by these şakşaks, one of which is ring-shaped, the woman of the house opens the door upon understanding whether the incoming person is a foreigner or a person who can enter the house freely. The doors in the Houses of Sivas contain two distinct knockers, i.e. tokmak (knocker) and zelve (someone who can enter the house freely) [16]. In the houses of Kayseri, the door leaf contains two tokmaks for the use by people from different genders so that when someone knocks at the door, the owner of the house understands whether the incoming person is male or female and opens the door [7]. In the Houses of Erzurum, however, the wooden door lattices called "tırhıç", inserted in front of the doors of houses, and preventing the inside from being seen while sitting at the courtyard in summer can be mentioned as a characteristic façade element which is the reflection of privacy [8].

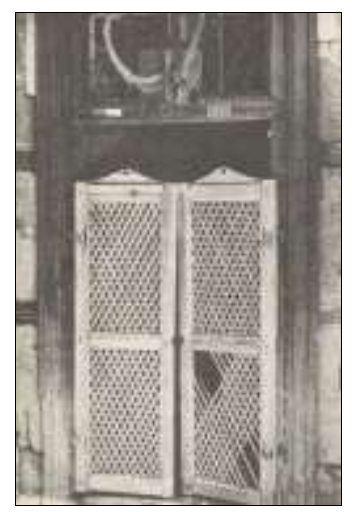

Figure 12. "Tirhıç" - the wooden door lattices [8].

Reference: Karpuz, 1984, p.112.

Apart from these elements on the façade, the formations in the interior space can also be given as examples of the reflection of privacy. In the Houses of Safranbolu, the element of "dönme dolap" between harem and selamlık spaces is an architectural solution created to allow the woman of the house to serve coffee, dessert, etc. without being seen by the male guests in the selamlı. The trays which contain the things served are left onto a rotating cylindrical wooden element by the woman of the house. In the selamlik, the man of the house takes the trays and presents them to the guests [15].

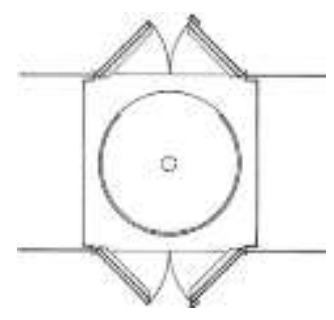

Figure 13. The "dönme dolap" element used in Safranbolu Houses [15]. Reference: Günay, 1999², p.105.

A different reflection of privacy in Muslim-Turkish Houses is the indirect entrances into the corner rooms. The spaces concerned, which have a lower ceiling than the height of the room, prevent the room from being perceived directly. Furthermore, from time to time, a controlled entry into the room is provided by hanging up a curtain to the arched passage or the door opening occurring here. In this context, the room includes the spaces of entrance, sekialt1, and sekiüstü in the Turkish house. 


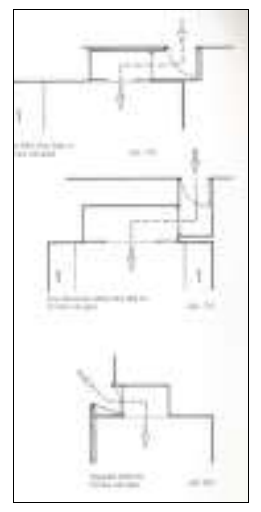

Figure 14. Indirect entrances into the corner rooms in Muslim-Turkish Houses [15]. Reference: Günay,1999², p. 143

3.3. In terms of Spatial Separation. In Muslim-Turkish houses, the spaces for females and males have been separated under the impacts of religion and culture. Depending on the size of the house and the economic power of the family, this separation sometimes emerges in the form of distinct building masses but is sometimes seen in the form of two adjacent building masses or the spaces which separate in the same house. When the spaces concerned are located within the same building mass in corner houses, the entries into the harem and the selamlı are accepted from different streets and the building is entered through different staircases. In the staircases analyzed as being adjacent, however, the element of lattice is used in between. The orders of location of the spaces in the harem and the selamlik differ in houses. On the other hand, some spaces are located at both sections. For instance, the hayat, the geometric center of the house in the houses of Kayseri, takes the name "içeri hayat" at the harem section but "dışarı hayat" at the selamlık section.

3.4. In terms of Location. The houses located on the streets at the Turkish neighborhoods which are organic, which narrow and expand from place to place, which reflect activity in the third dimension with the elements of bordering buildings such as protrusions and eaves, and which offer spaces with surprises have been formed by considering the understanding of privacy in terms of not only the privacy of the house but also the privacy of the environment and the neighbor. In this context, attention has been paid to the fact that the protrusions and window openings of the houses do not face each other on the street fabric. In other words, the openings on the façade of the building have been located in such a way that will not damage the privacy of the neighbor. The windows of houses are prevented from facing each other by differently locating the openings on the opposite protrusions of the houses on narrow streets. In this context, when the front face contains windows in one of the protrusions, it is seen that windows are opened only on the lateral faces in the protrusion of its opposite house. The effect of privacy is reflected by showing sensitivity to the formation of adjacent houses besides opposite houses. In the houses which are side by side, attention is also paid to the fact that the openings do not face the garden of the neighbor.

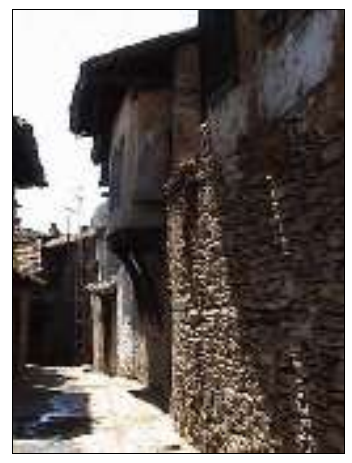

Figure 15. Organic streets in Birgi (Ödemiş) 
4. Elements of Identity. Religious elements and elements which reflect the Turkish identity are often perceived on the façades of Muslim-Turkish Houses. In this context, the deer antlers placed to avoid evil actions attract attention, along with tughras, writing of Maşallah, and prayers. The deer antlers considered to bring good luck were frequently used at the corners of the eaves of the houses particularly in the Yörük Village of Safranbolu. The writing of Maşallah is sometimes included in a decorative order or sometimes placed within a baroque frame together with the construction year of the building. It is seen that the animal tree motif was also used in the building façade decorations in relation to the beliefs. The Turkish identity is generally emphasized with the crescent and star motif on the façade.
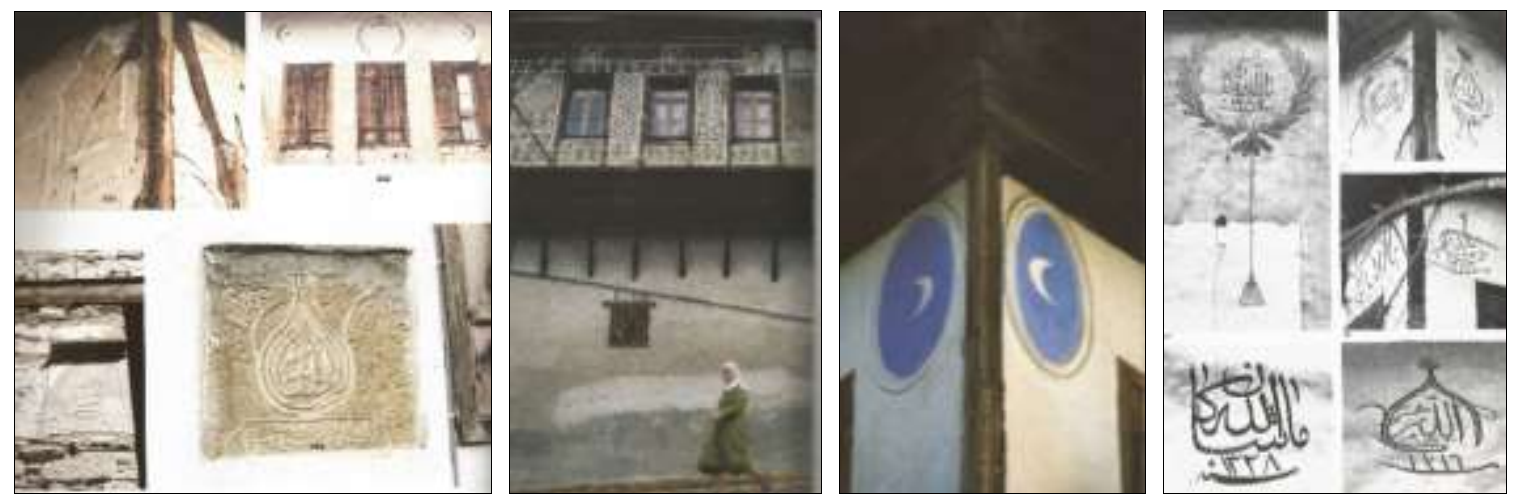

Figure 16-19. Identity elements in Muslim-Turkish Houses [17, 18, 18, 15]

References: Hersek, Meraki, 1999, p.104 (16); Eczacıbaşı, 2003, p.160 (17); Eczacıbaş1, 2003, p.99 (18); Günay, $1999^{2}$, p. 331 (19).

5. Conclusion. Although the conceptual discussions on the Turkish House make different assumptions correct according to the perspective, it is indisputable that the effect of culture is the most determining element in the formation of the house. Inwardness, the reflection of privacy observed in Muslim-Turkish Houses, has been reflected in every corner of the house from spatial separation to spatial elements and from the façade opening order to details in different dimensions. From the extant examples, it is also possible to see these formations and make readings of, and state opinions about, the lifestyle, spatial understanding, and philosophy of life of their periods.

\section{REFERENCES}

[1] Aksoy, E. (1963). Orta Mekan: Türk Sivil Mimarisinde Temel Kuruluş Prensibi. Mimarlık ve Sanat, 20, 39-92.

[2] Küçükerman, Ö. (1973). Anadolu'daki geleneksel Türk evinde mekân organizasyonu açısından odalar. Apa Ofset Basımevi.

[3] Eldem, S. H. (1968). Türk Evi Plan Tipleri.

[4] Kuban, D. (1995). Türk Hayatlı Evi. Misırlı Matbaacilık A.Ş.

[5] Arel, A. (1982). Osmanlı konut geleneğinde tarihsel sorunlar. Ege Üniversitesi Güzel Sanatlar Fakültesi.

[6] Erdim, M. (1980). "Anadolu'da Geleneksel Konut Birimi" Art Zamanlı ve Eş zamanlı İlişkilerin İrdelenmesi ve Fırat Havzası Konutlarında Plan Tipolojilerinin Çözümlenmesi Üzerine Bir Yöntem Araştırması. İzmir: Ege Güzel Sanatlar Fakültesi Doktora Tezi.

[7] Büyükmıhçı, G. (2005). Kayseri'de yaşam ve konut kültürü. Erciyes Üniversitesi.

[8] Karpuz, H. (1984). Türk İslâm mesken mimarisinde Erzurum evleri (Vol. 562). Kültür ve Turizm Bakanlığı.

[9] Şenol, S. (2007). Anadolu Türk konut mimarisinde Divriği evleri. Sivas Valiliği İl Kültür ve Turizm Müdürlüğü. 
[10] Yürekli, H., \& Yürekli, F. (2005). Türk Evi: The Turkish House: Gözlemler-Yorumlar: A concise Re-evaluation. Yap1 Yayın.

[11] Tuztaşı, U., \& Aşkun, İ. Y. (2013) "Türk Evi” İdealleştirmesinde "Osmanlı Evi” ve "Anadolu Evi” Kavramlarının Ortaklıklarına İlişkin İşlevsel Açıklamalar. Bilig, 66, 273.

[12] Akın, N. (1996).Osmanlı Döneminde Anadolu konutuyla Balkan konutu arasındaki ortaklıklar. Tarihten Günümüze Anadolu'da Konut ve Yerleşme. Ed. Sey, Y. Istanbul: History Foundation Publications, 269-277.

[13] Akın, N. (2001). Balkanlarda Osmanlı dönemi konutları. Literatür.

[14] Philippidēs, D. (1983). Greek Traditional Architecture: Eastern Aegean, Sporades-Ionian Islands (Vol. 1). Melissa.

[15] Günay, R. (1999). Türk Ev Geleneği ve Safranbolu Evleri. Yap1-Endüstri Merkezi Yayınları.

[16] Bilget, N. B. (1992). Sivas evleri (Vol. 1403). Kültür Bakanlığı.

[17] Hersek, C., Özköse, A., Günel, G., Meraki, Ş., Meraki, F., Maden, M., \& Öztunç, F. (1999). Safranbolu Yörükköyü ve mimari dokusu. Safranbolu Geleneksel Yaşam Biçimi ve Evleri. Yörükköyü Kültür Mirasını Koruma Tanıtma ve Dayanışma Vakfı, Kuban Matbaacılık, İstanbul.

[18] Eczacıbaşı. (2003). Evler - Houses. ed. Ş. Eczacıbaşı, Aksoy Matbaacılık, İstanbul. 